has nothing of significance in his family history. His personal history prior to the actual onset of the present trouble has a certain bearing on the case, and is, briefly, as follows: Patient is an only child. He is in his third year in a suburban High School and is said to be a student. He has had no bodily injuries of moment, has experienced no infection of any sort, and does not drink or smoke. Fon1 years ago he was treated at the Massachusetts General Hospital for twitching or tremor of the left hand, which recurred a year later. During these attacks he was unable to hold things securely in the affected hand.

For the past year he has had sudden transitory attacks of numbness of the left sicle of the body, of short duration. These attacks are said to occur more particularly while the patient is studying. Six months ago it was noticel that the right side of the nose was beginning to shrink, and slirinkage was subsequently noted on the riglit side of the forehead also. The wasting has bcen accompanied by more or less pain limited to the right side of the face, and by healache confined to the same side of the head. For four montls patient has noticed a dragging feeling in the right side of the nose and right half of the forehead, and this feeling has been emphasized for the past month by the simultaneous occurrence of transient vertigo acconipanied by peculiar alteration of consciousness. During these vertiginous attacks patient appears to know where he is and says he can speak, but hie mind doesn't work normally. He becomes confused in his recitations and has difficulty in grasping what the teacher says.

Physical examination slows a hemiatrophy sharply linited to the tissues of the right side of the face. The line of demarcation is particularly noticable on the forelead. On the right side of the forehead is a contracted scar of a dull white color. No other leucodermal manifestations are present. The right naso-labial fold is flattened somewhat; the brow wrinkles normally. The cartilaginous scaffolding of the nose is markedly shrunken on the right, but sulell is not affected. The intrinsic muscles of the face are spared; likewise the masseters. The tongue is tremulous and apparently slightly shrunken on the right half. Taste is completely lost on the right half of the tongue, both anteriorly and posteriorly. The palate and fauces are normal both sicles. The pupils are regular, equal and normal to tests of light and accommodation; the muscular movements of the eycballs are normal. The eyelaslies, eycbrows, and hair have neither clianged color or fallen out. There is diminished appreciation of lieat and cold on the right side of the face, but sensation is not otherwise disturbed. There is a fine tremor of both hands greatly increased on rotation. The muscles of trunk and extremities are normal. The teeth and jaws are normal.

Dr. Courtney did not think that in this case the disease lad attained to its full development. He did not propose to say anything concerning the pathology of the condition at this time, but hoped to show both this and his other two cases again, after they had been subjected to the paraffine treatment.

\title{
HYSTERICAL HYPERTHERMIA.
}

By Dr. G. L. Walton.

The case was one of high temperature of probable nervous origin. A boy of eight (seen in consultation with Dr. Bush), unustually studious and mentally active, became greatly excited over a coming exhibition. He was also knocked down a week before by a larger boy who is said to have sat upon the side of his head. This experience was followed by headache, lasting a few days; there were no further symptons. During the following week the temperature rose steadily to $105^{\circ} \mathrm{F}$. There was no restlessness, no disturbance of consciousness, no retraction of the head, no ocular or other cerebral symptom, no bleeding from the ear or nose, and no subconjunctival hemorrhage. The urine was normal and 
there was no digestive or other general disturbance. There was history of a similar experience a year ago but withont quite so high a temperature.

Careful examination showed no disturbance of motor, sensory, reflex, or other function. The skin was natural, warm; the pupils were widely dilated, but reacted perfectly to light. The boy was bright and intelligent without restlessness or sign of discomfort. The blood pressure was 70. The temperature, taken by the mouth under the direct observation of the physicians, was $104.7^{\circ} \mathrm{F}$. The conditions were unchanged for a week, after which the temperature gradually lessened during several months. The boy has been well since. The absence of constitutional symptoms rule out infection, and the nervous origin of the temperature was rendered the more probable by the neurotic constitution of the child and the history of a similar previous experience. Such a case can, however, be hardly regarded as fever in the ordinary acceptation of the term, and the question suggests itself whether the high temperature in such a case may not represent a local hysterical manifestation rather than the general body temperature.

Dr. Knapp recalled a case of hysteria which came tunder his obscrvation at the City Hospital nearly twenty-five years ago. which Dr. Edes doubtless remembered. She had very profonnd right hemianesthesia involving the special sense with right hemiplegia. At times she had a high temperature, as high as $105^{\circ} \mathrm{F}$, while at other times the temperature sank to $95^{\circ}$. Very careful investigations were made and no source of the fever other than the hysteria could be found. Dr. Knapp thouglit that Dr. Walton's suggestion of a local rise of temperature is somewhat fanciful, yet in this case there was noted for a long time a difference of axillary temperature on the two sides of from one to four degrecs. For a time the temperature of the anesthetic side was the lower, but later on the temperature of that side was higher. Sphygmographic tracings on the two sicles showed a difference, the pulse curve on the anesthetic sicle showing at times a greater tension and at other times a lower tension and a more acute rise than that on the other side.

Dr. Courtney, apropos of Dr. Walton's communication, wished to mention a case which he had had under observation for a long time. It is that of a girl of about is years, who first came to the clinic complaining of persistent headache. Physical examination revealed nothing to account either for the headache or for the fact that the patient's daily temperature had been $100^{\circ}$ or $100.5^{\circ}$ for a matter of three years. The patient is an inveterate neuropath and has recently developed a form of myospasm. which strongly suggests paranyoclonus multiplex. He was inclined to attribute the increased heat production in the case to nervous influences alone.

Dr. Mitchell said that he had made some observations upon the effects of exercise in healthy men that might be of indirect interest in connection with this subject. Three healthy young nen. on six different occasions, had been given exercise for one hour playing baseball. The days were warm and perspiration profuse. Rectal temperatures before the exercise were never above $99.4^{\circ}$, and the rectal temperatures taken at the end of exercise ranged as follows: The lowest of the eighteen temperatures was $102.2^{\circ}$, and the highest $102.8^{\circ}$ In each instance the temperature fell to normal, following bath and rest, and there was never any sense of elevated temperature.

\section{GENERAL ENCEPHALOMACIA.}

By Drs. Southard and Hodskins.

The speakers proposed to define a type of soft brain differing, on the one hand, from encephalomalacia, due to plugging of vessels, and on the other hand from autolytic softening of post-mortem origin. They termed the condition general encephalomalacia. The condition is characterized by (I) Diffuse axonal reactions in many types of cell; (2) diffuse fatty de- 